\title{
Dūstantis pacientas: šeimos gydytojo taktika
}

\author{
Gediminas Urbonas \\ LSMU MA Šeimos medicinos klinika
}

Reikšminiai žodžiai: dusulys, šeimos gydytojas, pirminẻ sveikatos priežiūra.

Santrauka. Dusulys literatūroje apibrěžiamas kaip sunkaus kvėpavimo pojūtis, priklausantis ne tik nuo patofiziologinių pokyčių žmogaus organizme, bet ir nuo paciento emocinès būklès bei jo charakterio savybių. Dusulys skiriamas ị ūminį ir lètinį. Staiga atsiradus dusuliui, pacientai dažniausiai patenka tiesiai i skubiosios pagalbos skyrių, ambulatoriškai konsultuojami retai. Lètinio dusulio atveju šeimos gydytojui dažniausiai tenka atskirti, širdies ar plaučių ligos ji sukelia; neretai abiejų organų patologija būna kartu. Diferencijuojant dusulio priežasț, itin svarbi anamnezė. Dusulys iškvėpimo metu būdingas tiek plaučių, tiek širdies patologijai. Nervinės kilmės dusuliui būdinga tai, kad dusulys prasideda ramybėje, pacientui sunku j̨kvėpti. Dusulio diferencinei diagnostikai būtinas spirometrinis tyrimas. Neaiškiais atvejais šeimos gydytojas turètų siųsti pacientus pas kardiologą ir (ar) pulmonologą diagnozės patikslinti.

Dusulys - dažnas pacientų nusiskundimas, girdimas šeimos gydytojo kabinete. Nors iš pirmo žvilgsnio simptomas aiškus ir visiems suprantamas, pacientai dusulị apibūdina ịvairiai: sunkumas, veržimas, diskomfortas krūtinèje; oro stoka; švokštimas ir t. t. Dusulys literatūroje apibrèžiamas kaip sunkaus kvèpavimo pojūtis, priklausantis ne tik nuo patofiziologinių pokyčių žmogaus organizme, bet ir nuo paciento emocinès būklès bei jo charakterio savybių.

Dusulys skiriamas i ùmini ir lètini. Staiga atsiradus dusuliui, pacientai dažniausiai patenka tiesiai ị skubiosios pagalbos skyrių, ten apžiūrimi ir, esant reikalui, hospitalizuojami. Jei toks pacientas konsultuojamas ambulatoriškai, šeimos gydytojui reikètų prisiminti dažniausias ūminio dusulio priežastis (1 lentelè). Preliminarią diagnozę padeda nustatyti anamnezè (pirmą kartą atsiradęs ar pasikartojantis dusulys, anksčiau diagnozuotos ligos ir kt.), dusuli lydintys simptomai (karščiavimas, kosulys, odos pokyčiai ir pan.), objektyvus tyrimas (plaučių ir širdies auskultacijos duomenys) bei greitai atliekami ir kiekvienam šeimos gydytojui prieinami instrumentiniai tyrimai (EKG). Šeimos gydytojo taktika ūminio dusulio atveju priklauso nuo dusulio intensyvumo ir itariamos ligos. Jei akivaizdu, kad reikia stacionarinio gydymo, pacientas turètų būti skubiai siunčiamas ị skubiosios pagalbos skyrių tokios ligoninès, kurioje yra konkretaus atvejo gydymui būtinos pagalbos priemonès.

Lètinis dusulys šeimos gydytojui sukelia daugiau keblumų. Dažniausiai tenka atskirti, ar jis nulemtas širdies ar plaučių ligų; neretai abiejų organų patologija būna kartu (2 lentelè). Tokiais atvejais konsultacijos metu būtina nustatyti, kuri patologija vyrauja. Šeimos gydytojo taktika priklauso nuo paciento funkcinès būklès, organo nepakankamumo laipsnio ir prognozès.

Lètinị dusulị dažniausiai sukelia širdies ar / ir plaučių nepakankamumas. Dèl deguonies stokos suaktyvejja audinių metabolizmą reguliuojantys receptoriai, o tai sąlygoja centrinès nervu sistemos stimuliaciją ir kvépavimo raumenų susitraukimą.

Diferencijuojant dusulio priežasti, itin svarbi anamnezè. Kai kurių autorių duomenimis, vien tinkamai surinkta informacija dusulio priežastị padeda nustatyti 75 proc. atvejų. Jei pacientas skundžiasi dusuliu, būtina išsiaiškinti dusulio pobūdi (nuolatinis ar priepuolinis); sąlygas, predisponuojančias dusulio atsiradimą; dusulio trukmę; aplinkybes, kurioms esant dusulys išnyksta ar palengvèja; dusuli lydinčius simptomus. Nepaisant to, kai kuriais atvejais atsakyti i klausimą, širdies ar plaučiu patologija sąlygoja dusuli, būna sunku. Dusulys iškvèpimo metu būdingas tiek plaučių, tiek širdies patologijai. Nors manoma, kad dusulio
1 lentelè. Dažniausios ūminio dusulio priežastys

- Staigus širdies (kairiojo skilvelio) funkcijos sutrikimas

Bronchospazmas

- Pneumonija

- Plaučiuc embolija

- Nerimas (panikos priepuolis)

2 lentelè. Dažniausios lètinio dusulio priežastys

Širdies ligos

- Lètinis širdies nepakankamumas

- Dviburio vožtuvo ligos (stenozè, nesandarumas)

Plaučiu patologija

- Lètinè obstrukcinè plaučių liga

- Sunki astma

- Intersticinès plaučiuc ligos

- Plautiné hipertenzija

Mechaniniai veiksniai

- Kifoskoliozè

- Ascitas

- Nutukimas

- Skystis pleuros ertmėje

Psichikos sutrikimai

- Generalizuotas nerimas, panikos priepuoliai Kraujo ligos

- Lètinè mažakraujystė

priepuoliai naktị būdingesni širdies nepakankamumui, tuo gali skustis ir plaučiu liga sergantis pacientas. Pavyzdžiui, lètinès obstrukcinès plaučiuc ligos (LOPL) atveju nakti neretai sustiprejja kvėpavimo taku sekrecija ir sąlygoja bronchų obstrukciją. Dèl obstrukcijos pacientas pajunta dusuli, verčianti atsisèsti. Toks paciento patiriamas simptomas gali sąlygoti klaidingą širdies astmos diagnozę.

Švokštimas nèra specifinis konkretaus organo pažeidimo simptomas ir 
rodo stambiųjų bronchų spazmą, kurị gali sąlygoti tiek obstrukcinė plaučių liga, tiek širdies nepakankamumas. Todèl itin svarbi gyvenimo ir ligos anamnezè. Jei dusulị lydi nuolatinis kosulys, skrepliavimas, pasikartojančios kvėpavimo takų infekcijos, yra rūkymo ar žalingu darbo sąlygu anamnezè - labiau tikètina plaučiu patologija. Bet ir tokiais atvejais būtina prisiminti, kad dusulys gali būti mišrios kilmès. Sausas, neatkosint skreplių kosulys gali būti širdies nepakankamumo sąlygoto dusulio atitikmuo, jei atsiranda fizinès itampos metu ar gulint ir palengveja gydant širdies nepakankamumą.

Generalizuoto nerimo atveju paciento nusiskundimai gali priminti širdies ar plaučių patologijos sąlygotą dusuli. Panikos priepuoliams būdinga tai, kad dusulys prasideda ramybeje, pacientui sunku itkvèpti; dusuli lydi spaudimas krūtinèje bei oro stoka. Diferencinès diagnostikos sunkumu kyla, kai kartu yra ir minimaliu objektyvių širdies ar plaučiu ligos požymių. Diferencijuoti padeda dusuli lydintys emociniai pergyvenimai ir daug kitu juntamų negalavimų (pvz., virškinimo takto), neturinčių morfologinio pagrindo. Generalizuoto nerimo sąlygotą dusuli reikètu atskirti ne tiek nuo LOPL ar širdies nepakankamumo, kiek nuo plaučių hipertenzijos simptomų; kartais jaunu pacientu patiriamas plautinès hipertenzijos sukeltas dusulys gali būti palaikytas nervinès kilmès dusuliu.

Konsultacijos metu reikia ịvertinti ir fizinio krūvio, sąlygojančio dusulị, intensyvumą; pažeisto organo funkcijos nepakankamumo laipsni bei ìvertinti ligos sunkumą. Dèl darbo specifikos (tęstinè sveikatos priežiūra, tų pačių pacientų konsultavimas ilgą laiką) šeimos gydytojas turi unikalią galimybę stebèti ligos pokyčius ir palyginti paciento nurodomus simptomus su kitų to paties amžiaus žmonių nusiskundimais. Vertindamas dusulį lydinčius simptomus, šeimos gydytojas paciento turètų paklausti, ar neatkosi kraujo. Esant šiam simptomui, reikètu pagalvoti apie emboliją $\mathfrak{i}$ plaučius, plaučių vẻžị, bronchektazes.

Fizinio tyrimo metu pirmiausia būtina atkreipti dėmesi i $\mathfrak{i}$ širdies susitraukimu ir kvėpavimo dažnį. Kūno svorio didejjimą gali sąlygoti pablogèjęs širdies nepakankamumas. Krūtinès ląstos apžiūra (pvz., matomas pagalbinių raumenų dalyvavimas kvėpuojant) ne tik padeda "objektyvizuoti“ dusuli, bet ir leidžia nustatyti, ar nèra krūtinès ląstos kaulinès patologijos (pvz., kifoskoliozès), galinčios sąlygoti dusulị. Plaučiu auskultacija šeimos gydytojo darbe itin vertinga, kai girdima sausu cypiančių (astma, LOPL) ar drégnų krepituojančių (širdies nepakankamumas) karkalų.

Dusuliu besiskundžiančiam pacientui šeimos gydytojas būtinai turi atlikti krūtinès ląstos rentgenogramą ir EKG. Rentgenogramoje reikia įvertinti plaučių venų būklę, infiltratus, galimus intersticinius pakitimus, širdies dydi ir kalcifikatus. Širdies nepakankamumo atveju EKG gali būti randami kairiosios širdies dalies, plaučių ligų atveju plaučių hipertenzijos sąlygoti dešiniosios širdies dalies pažeidimo požymiai. Dusulio diferencinei diagnostikai būtinas spirometrinis tyrimas. Šeimos gydytojo darbe pakanka paprasčiausio spirometro, matuojančio $\mathrm{FEV}_{1}$ ir FVC. Šiu rodiklių pakanka, kad ne tik būtų nustatytas vyraujantis kvejpavimo funkcijos surikimo pobūdis (obstrukcija ar restrikcija), bet ir sutrikimo sunkumas. Deja, spirometrinis tyrimas Lietuvos šeimos gydytojo darbe atliekamas retai, todèl neatmestina tikimybè, kad dalis LOPL atvejų lieka nediagnozuoti. Lietuvoje galiojantis širdies nepakankamumo diagnostikos ir gydymo aprašas nurodo, kokius tyrimus gydytojas privalo atlikti, diagnozuodamas širdies nepakankamumą. Kai diferencinė diagnostika sunki, rekomenduojama atlikti natriurezinių peptidu (BNP) koncentracijos tyrimus. Šie tyrimai itin naudingi, kai pacientas serga ir lètine obstrukcine plaučių liga, ir širdies nepakankamumu. BNP turi ir prognozinę vertę, tačiau jų įtaka vertinant gydymo veiksmingumą dar nèra apibrezžta. Kadangi šie ir būtini instrumentiniai tyrimai (pvz., širdies echoskopija) neatliekami pirmineje sveikatos priežiūros grandyje, neaiškiais atvejais šeimos gydytojas turètu siųsti pacientus pas kardiologą ir (ar) pulmonologą diagnozès patikslinti.

Nustačius lètinio dusulio priežastị, svarbus lètine liga sergančio paciento mokymas. Apie gydymą bei paūmèjimụ profilaktiką turi būti informuoti ir ligonio artimieji. Tuo turètų užsiimti ne tik pats šeimos gydytojas, bet ir kartu dirbanti slaugytoja. Mokytas pacientas ir jo artimieji turi ne tik vengti pablogejjimų, bet ir žinoti konkrečias priemones, kurių turi imtis ištikus pa- ūmejjimui. Šeimos gydytojas kiekvienos konsultacijos metu turi skatinti pacientą atsisakyti žalingu ipročių (pvz., rūkymo), jei tokių esama. Pirminès sveikatos priežiūros specialistų vaidmuo itin svarbus taikant suaugusiųju imunoprofilaktiką. Tiek dèl širdies nepakankamumo, tiek dèl lètinès plaučių ligos dusulị jaučiantis pacientas turètų būti paskiepytas pneumokoko vakcina ir kasmet sezoninio gripo vakcina. Čia vèl svarbus ne tik šeimos gydytojo, bet ir jo komandos (slaugytojų) vaidmuo.

Ypatingą vietą šeimos gydytojo darbe užima dūstantis, namuose slaugomas pacientas. Ambulatorinè specialisto konsultacija (ne tik sudètingesni tyrimai, bet ir krūtinès ląstos rentgenograma) tokiu atveju ligoniui tampa sunkiai pasiekiama. Lankydamas pacientą namuose, šeimos gydytojas visu pirma turi įvertinti paciento būklès stabilumą. Dusuliui sustiprèjus, ypač jei būklè greitai blogèja ir / ar kartojasi naktinis dusulys, pacientas turètų būti nedelsiant siunčiamas gydyti ị stacionarą.

\section{EVALUATION OF DYSPNEA IN GENERAL PRACTICE}

\section{GEDIMINAS URBONAS \\ FAMILY MEDICINE DEPARTMENT, KAUNAS UNIVERSITY OF HEALTH SCIENCES}

Keywords: dyspnea, general practitioner, primary health care. Summary. Dyspnea is the subjective sensation of difficult breathing and depend not only on patophysiological changes but on patient emotional status also. In case of acute dyspnea patient often presents in the urgent care setting and rarely in the primary care practice. Heart and lung diseases account for most cases of chronic dyspnea. At times, the differentiation can be difficult; moreover, these causes often coexist. History remains the single most useful diagnostic modality. Exertional dyspnea occurs in both cardiac and pulmonary disease. Onset at rest in conjunction with inability to take in air are characteristic features of chronic anxiety. Simple pulmonary function tests are necessary for the diferential diagnosis. In case if diagnosis remains unclear patients should be referred to pulmonologist or cardiologist.

\section{LITERATŪRA}

1. Širdies ligos: universiteto vadovèlis. Sudarytojas Remigijus Žaliūnas. Kaunas: UAB Kardiologijos projektai, 2009.

2. Vidaus ligu diagnostikos pagrindai: vadovèlis. Albinas Naudžiūnas, Saulius Sadauskas, Alvydas Unikauskas ir kt. Kaunas: UAB Vitae Litera, 2013.

3. Primary care medicine: office evaluation and management of adult patient. Edited by Allan H. Goroll, Lawrence A. May, Albert G. Mulley et al. Boston, 2000; 267-271. 